\title{
Effect of Canning/Thermal Processing on Quality Characteristics of Yakhni
}

\author{
Sajad A Rather, FA Masoodi*, SM Wani and Adil Gani, \\ Department of Food Science and Technology, University of Kashmir, India
}

Submission: February 20, 2017; Published: March 23, 2017

*Corresponding author: FA Masoodi, Department of Food Science and Technology, University of Kashmir, Srinagar-190006, India, Tel: +91-9419135876; Email: masoodi_fa@yahoo.co.in

\begin{abstract}
The study was conducted to analyze the effect of goshtaba products with varying levels of fat and different gums and canning/thermal processing on the proximate composition and microbial stability of yakhni (gravy). The results indicated that non-significant difference was observed in moisture, protein, fat and ash contents in all formulations after canning ( $\mathrm{P}>0.05)$, except yakhni from high fat control formulation which showed significantly higher fat content $(\mathrm{P}<0.05)$. Incorporation of different gums in goshtaba products showed non-significant effect on proximate of yakhni formulations $(\mathrm{P}>0.05)$. Microbial evaluation exhibited that after heat processing no viable microbes was recovered from any of the yakhni formulations. Thus all yakhni formulations were commercially sterile.
\end{abstract}

Keywords: Yakhni; Canning; Proximate composition; Microbial evaluation

\section{Introduction}

The state of Jammu and Kashmir in India is widely known for wazwan, which is a multi-course meal in Kashmiri cuisine. The preparation of wazwan is considered an art and a point of pride in Kashmiri culture and identity. Yakhni forms the essential component of Kashmiri wazwan. Yakhni is prepared from curd, water, hydrogenated vegetable oil, spices and condiments along with the meat balls (Goshtaba) or mutton pieces. This recipe has mouth-watering flavours that can tempt any one and is usually served with steamed rice. Aromatic spices included fennel seeds, cinnamon, cardamom, cloves etc. are added which are responsible for unique taste and flavour of yakhni.

Dairy and meat products when stored at room temperature can serve as an excellent medium for growth of microorganisms, since they are a good source of amino acids and nitrogen [1]. When these microorganisms multiply, they produce toxins that are hazardous and even lethal to humans [2]. Indian dairy and meat processing is focusing on export, looking for unique shelf stable products for national and international markets. High perishability of yakhni is a serious problem for its commercialization. Thus the preservation alternative that may enhance the shelf life of this product at ambient temperature is important so that this good protein source can be offered to other regions of the country and to promote its export potential. There are many methods of production, thermal processing is one the promising method of processing food products [3].
Thermal processing has been widely used in food processing to produce microbiologically safe products having acceptable eating quality. Commercial thermal processing ensures a reduction or inactivation of spore-forming microorganisms sufficient to guarantee commercial sterility. Canning is a way of value addition of food products that can be served to consumers for more than 2 years, and it continues to be the most preferred and convenient technique of preservation to produce shelf stable products that can be stored at ambient temperatures [4]. The objective of this study was to evaluate the effect of canning on proximate composition and microbial stability of yakhni a traditional curd and meat based product of Jammu and Kashmir, India.

\section{Materials and Methods}

\section{Materials}

Fresh boneless mutton and mutton fat from three different male sheep were purchased on three different occasions from a local butcher at Hazratbal Srinagar, India. Non-meat ingredients, salt, fresh curd from cow's milk, oil and spices were procured from the local market. Guar gum used in this study was procured from Hi-Media Pvt. Ltd., Mumbai India.

Formulation of yakhni Lean meat and mutton fat were initially ground separately in a mincer (SIRMAN, TC 22, Italy) through an 8-mm plate and divided into five parts for various 
formulations, which differed in composition with respect to fat content and guar gum level. Each treatment, which comprised of a formulation with a specific composition in terms of fat and gum level, was triplicated in each batch. The first formulation was used as high (regular) fat control and fat content was adjusted to $20 \%$ by the addition of mutton fat. The second formulation was used as low fat control and fat content was adjusted to $10 \%$ by the addition of mutton fat. The other formulations were supplemented with various levels of guar gum $0.5 \%$, $1 \%$, and $1.5 \%$ and fat content was adjusted to $10 \%$ with the addition of mutton fat. After addition of the fat replacers the emulsion formulations were first subjected to manual mixing and then homogenized in a blender for $2 \mathrm{~min}$ to ensure uniform distribution of the fat replacer.

The remaining non-meat ingredients (salt 2.5\%, black cardamom seeds $0.2 \%$ and cumin $0.1 \%$ ) were then added to the mixture and mixed for eight additional min to make homogenous viscoelastic like mass. The mixtures were reground separately in a mincer (SIRMAN, TC 22, Italy) through a 6-mm plate. The temperature of emulsion was maintained below $10{ }^{\circ} \mathrm{C}$ during mincing by using all the relevant materials under chilled conditions and addition of chilled water. Meat balls weighing 50$60 \mathrm{~g}$ and diameter of about $60 \mathrm{~mm}$ were made from the material. The balls were rolled between palms to achieve their sphericity. The meat balls from each batch were then processed in curd (gravy) separately to get goshtaba and yakhni as the finished products.

Table 1: Standardized recipe for yakhni preparation.

\begin{tabular}{|c|c|}
\hline Ingredient & Quantity \\
\hline Water & $1000.00 \mathrm{~mL}$ \\
\hline Curd (Dahi) & $1000.00 \mathrm{~mL}$ \\
\hline Hydrogenated vegetable oil & $100.00(\mathrm{~g})$ \\
\hline Black cardamom & $2.50(\mathrm{~g})$ \\
\hline Green cardamom & $1.00(\mathrm{~g})$ \\
\hline Cinnamon & $3.50(\mathrm{~g})$ \\
\hline Cloves & $0.50(\mathrm{~g})$ \\
\hline Dried ginger powder & $6.00(\mathrm{~g})$ \\
\hline Aniseed powder & $8.00(\mathrm{~g})$ \\
\hline Garlic paste & $10.00(\mathrm{~g})$ \\
\hline Fried onion paste & $50.00(\mathrm{~g})$ \\
\hline Common salt & $13.00(\mathrm{~g})$ \\
\hline
\end{tabular}

Yakhni is the gravy, in which meat balls are processed (Table 1). For preparing yakhni two parts of fresh curd was homogenized with one part of water with a stirrer, transferred to a thick bottomed stainless steel vessel and heated rapidly on a gas stove for 10-15 minutes. During heating curd was constantly stirred until it reached the boiling point. Hydrogenated vegetable oil was added to it and boiling continued for 10-15 minutes. Then garlic paste was added followed by other spices i.e., black cardamom, green cardamom, cinnamon, cloves, dried ginger powder and aniseed powder, respectively. Fried onion paste was added at the end. Boiling was continued until the added oil floated back. At this stage, the remaining water was added and yakhni was cooked further for 10-15 minutes, to obtain a desirable consistency. Salt was added towards the end of cooking. The meat balls were then transferred to the boiling yakhni and cooked for $30 \mathrm{~min}$.

Canning/thermal processing of yakhni immediately after the preparation of product four meat balls about $200 \mathrm{~g}$ was packed into washed and cleaned tin cans. The hot gravy (yakhni) at $80 \pm 5{ }^{\circ} \mathrm{C}$ was then added to each can and lid was applied by single seaming operation. During can filling care was taken to avoid the gravy (yakhni) from contaminating the sealing area of the cans. Head space of about $10 \%$ was maintained from the can contents to allow the contents to boil during processing. The cans were exhausted under steam in an exhaust box (Bajaj India, AJAX) at $100{ }^{\circ} \mathrm{C}$ for $10 \mathrm{~min}$ and immediately double seamed in a double seaming machine. Thermal processing was then carried out in an over pressure autoclave (Yorco Sales Ltd., YSI-402D) at 121 ${ }^{\circ} \mathrm{C}$ and 15 psi pressure for about 35 minutes. The cans were cooled immediately by spraying chilled potable water under pressure to a specified temperature of $38{ }^{\circ} \mathrm{C}$, so as to prevent the proliferation of thermophiles and the product from getting over cooked. The cans were then air dried, labeled and kept at ambient temperature for two weeks for conditioning before analysis of yakhni.

\section{Proximate composition}

Moisture, protein, fat and ash contents were determined according to Association of Official Analytical Chemists [5].

\section{Microbiological evaluation}

Total plate count, coliform count, anaerobic plate count, clostridium count and yeast and mould counts of the yakhni samples were determined by standard methods. Readymade media from Hi-Media Laboratories (P) Ltd., Mumbai were used for the enumeration of different microbes.

\section{Statistical analysis}

All tests were done at least three times for each experimental condition and mean values are reported. Data were analyzed using general linear model (GLM) procedure of SPSS Statistics (v. 16, Inc., Chicago, IL) for two-way analyses of variance (ANOVA) as a function of formulation and storage period. Duncan's multiple range test $(\mathrm{P}<0.05)$ was used to determine the differences between means. The statistical analysis for each parameter combines the data from three batches.

\section{Results and Discussion}

\section{Proximate composition}

Consumers are interesting in the chemical composition of food product and are one of the most important criteria which consumers look for when purchasing the food product. Thus the changes in moisture, protein, fat and ash contents of yakhni 
during canning were monitored and the results are presented in Table 2. After canning the moisture content of yakhni from control formulations (YHFC, YLFC) increased slightly. However the yakhni from low fat formulations with gums exhibited lower values compared to their pre-canned counterparts ( $p>0.05)$. The slight decrease in moisture content of yakhni from low fat formulations after canning could be attributed to the absorption of moisture by the product incorporated with gums. Comparison of different yakhni samples reveals that the samples from control formulations (YHFC, YLFC) exhibited slightly higher moisture content compared to the samples from low fat formulations ( $p>0.05$ ). This slight variation in moisture content might be attributed to the higher protein oxidation in control goshtaba formulations resulting in higher release of water which is added during emulsion preparation, thus contributing to higher moisture content of yakhni (filling medium). The yakhni from control formulations (YHFC, YLFC) exhibited slight decrease while that from the low fat formulations exhibited slight increase in protein content following the canning process ( $p>0.05$ ). Changes in protein content of yakhni from different goshtaba products could be attributed to the changes in moisture content. The protein content of yakhni from low fat products was higher compared to the yakhni from control goshtaba and increased slightly with the increasing concentration of gums. This higher protein content might be due to the more water retained by low fat goshtaba products resulting in greater protein content of their respective gravy (yakhni) samples compared to the control formulations. After canning the yakhni from high fat goshtaba exhibited significant increase in fat content $(p<0.05)$, whereas yakhni from all low fat goshtaba products exhibited slight non-significant increase compared to the pre-canned samples Table 2: Effect of canning/thermal processing on ash content (percent)
( $p>0.05)$. A proportion of fat loss by goshtaba products into the filling medium (yakhni) during thermal processing might have contributed to the slight increase in fat content of yakhni after canning. Comparison of different samples reveals that yakhni from high fat control exhibited significantly higher fat content during the entire storage period than the yakhni from low fat goshtaba products $(\mathrm{p}<0.05)$. Though there was no variation in the initial composition of different yakhni samples, the higher fat content of yakhni from high fat goshtaba might be due to migration of fat from main product into its surrounding medium during thermal processing. Because the higher initial fat content in high fat goshtaba can create large fat pools, which helps fat to migrate out of the inner to the outer part of the goshtaba and resulting in higher fat loss into filling medium (yakhni) during thermal processing. After canning the yakhni from control goshtaba products exhibited slight increase in ash content, whereas the yakhni from low fat goshtaba products showed decrease in values, however the differences were non-significant ( $p>0.05$ ). This variability may be due to the changes in composition of the samples during thermal processing. Ash content is a measure of minerals in a food commodity. The slight increase in ash content of the yakhni samples from low fat goshtaba products might be attributed to the salt content increase during canning due to penetration of moisture from yakhni (filling medium) into goshtaba products containing gums. Comparison of different samples reveals that, the yakhni from low fat goshtaba products incorporated with gums exhibited slight higher values compared to the yakhni from control formulations ( $p>0.05$ ). This slight variation in ash content might be attributed to the variability in fat and moisture loss into yakhni from goshtaba products during thermal processing and subsequent storage.

of yakhni.

\begin{tabular}{|c|c|c|c|c|c|c|c|c|}
\hline \multirow[b]{2}{*}{ Treatments } & \multicolumn{2}{|c|}{ Moisture (\%) } & \multicolumn{2}{|c|}{ Protein (\%) } & \multirow[b]{2}{*}{$\begin{array}{l}\text { Pre-canned } \\
\text { Yakhni }\end{array}$} & \multirow{2}{*}{$\begin{array}{c}\text { Fat }(\%) \\
\text { canned Yakhni }\end{array}$} & \multicolumn{2}{|c|}{ Ash (\%) } \\
\hline & $\begin{array}{l}\text { Pre-canned } \\
\text { Yakhni }\end{array}$ & canned Yakhni & $\begin{array}{l}\text { Pre-canned } \\
\text { Yakhni }\end{array}$ & canned Yakhni & & & $\begin{array}{l}\text { Pre-canned } \\
\text { Yakhni }\end{array}$ & $\begin{array}{l}\text { canned } \\
\text { Yakhni }\end{array}$ \\
\hline YHFC & $80.00 \pm 1.12 \mathrm{abA}$ & $80.56 \pm 1.22 \mathrm{abA}$ & $3.67 \pm 0.64 \mathrm{aAB}$ & $3.60 \pm 0.43 \mathrm{aAB}$ & $6.53 \pm 0.33 \mathrm{aAB}$ & $7.18 \pm 0.36 \mathrm{bAB}$ & $2.54 \pm 0.14 \mathrm{aAB}$ & $2.50 \pm 0.09 \mathrm{aAB}$ \\
\hline YLFC & $80.30 \pm 0.97 \mathrm{abA}$ & $80.69 \pm 1.00 \mathrm{abA}$ & $3.60 \pm 0.49 \mathrm{aAB}$ & $3.54 \pm 0.62 \mathrm{aA}$ & $6.08 \pm 0.28 \mathrm{aAB}$ & $6.20 \pm 0.30 \mathrm{aAB}$ & $2.47 \pm 0.24 \mathrm{aAB}$ & $2.43 \pm 0.17 \mathrm{aAB}$ \\
\hline YGG1 & $79.81 \pm 1.10 \mathrm{aA}$ & $79.06 \pm 1.19 \mathrm{aA}$ & $3.61 \pm 0.41 \mathrm{aAB}$ & $3.63 \pm 0.37 \mathrm{aAB}$ & $6.09 \pm 0.60 \mathrm{aA}$ & $6.13 \pm 0.21 \mathrm{aA}$ & $2.50 \pm 0.33 \mathrm{aA}$ & $2.53 \pm 0.11 \mathrm{abAB}$ \\
\hline YGG2 & $79.85 \pm 1.07 \mathrm{aA}$ & $79.01 \pm 1.23 \mathrm{aA}$ & $3.63 \pm 0.72 \mathrm{aA}$ & $3.68 \pm 0.34 \mathrm{aAB}$ & $6.12 \pm 0.54 \mathrm{aA}$ & $6.16 \pm 0.17 \mathrm{aA}$ & $2.51 \pm 0.25 \mathrm{aAB}$ & $2.54 \pm 0.20 \mathrm{abAB}$ \\
\hline YGG3 & $79.77 \pm 1.01 \mathrm{aA}$ & $79.05 \pm 1.01 \mathrm{aA}$ & $3.64 \pm 0.62 \mathrm{aA}$ & $3.67 \pm 0.55 \mathrm{aAB}$ & $6.13 \pm 0.27 \mathrm{aA}$ & $6.19 \pm 0.63 \mathrm{aA}$ & $2.56 \pm 0.20 \mathrm{aAB}$ & $2.58 \pm 0.15 \mathrm{abB}$ \\
\hline YXG1 & $79.92 \pm 1.20 \mathrm{abA}$ & $79.07 \pm 1.22 \mathrm{aA}$ & $3.62 \pm 0.51 \mathrm{aA}$ & $3.66 \pm 0.47 \mathrm{aAB}$ & $6.08 \pm 0.19 \mathrm{aA}$ & $6.14 \pm 0.51 \mathrm{aA}$ & $2.53 \pm 0.16 \mathrm{aAB}$ & $2.55 \pm 0.14 \mathrm{abAB}$ \\
\hline YXG2 & $79.85 \pm 1.10 \mathrm{aA}$ & $79.16 \pm 1.20 \mathrm{aA}$ & $3.65 \pm 0.33 \mathrm{aAB}$ & $3.69 \pm 0.30 \mathrm{aAB}$ & $6.11 \pm 0.43 \mathrm{aA}$ & $6.15 \pm 0.40 \mathrm{aA}$ & $2.53 \pm 0.11 \mathrm{aAB}$ & $2.56 \pm 0.27 \mathrm{abAB}$ \\
\hline YXG3 & $79.77 \pm 1.13 \mathrm{aA}$ & $79.11 \pm 1.16 \mathrm{aA}$ & $3.64 \pm 0.46 \mathrm{aA}$ & $3.68 \pm 0.52 \mathrm{aA}$ & $6.12 \pm 0.32 \mathrm{aA}$ & $6.17 \pm 0.24 \mathrm{aA}$ & $2.52 \pm 0.23 \mathrm{aAB}$ & $2.57 \pm 0.30 \mathrm{abB}$ \\
\hline YGXG1 & $79.90 \pm 1.21 \mathrm{aA}$ & $79.10 \pm 1.20 \mathrm{aA}$ & $3.60 \pm 0.40 \mathrm{aA}$ & $3.65 \pm 0.66 \mathrm{aA}$ & $6.07 \pm 0.22 \mathrm{aA}$ & $6.12 \pm 0.16 \mathrm{aA}$ & $2.51 \pm 0.35 \mathrm{aAB}$ & $2.54 \pm 0.34 \mathrm{abAB}$ \\
\hline YGXG2 & $79.77 \pm 1.18 \mathrm{aA}$ & $79.04 \pm 1.14 \mathrm{aA}$ & $3.63 \pm 0.67 \mathrm{aA}$ & $3.67 \pm 0.37 \mathrm{aA}$ & $6.13 \pm 0.26 \mathrm{aA}$ & $6.19 \pm 0.14 \mathrm{aA}$ & $2.57 \pm 0.30 \mathrm{abAB}$ & $2.60 \pm 0.22 \mathrm{abAB}$ \\
\hline YGXG3 & $79.73 \pm 1.09 \mathrm{aA}$ & $79.00 \pm 1.42 \mathrm{aA}$ & $3.66 \pm 0.53 \mathrm{aA}$ & $3.69 \pm 0.41 \mathrm{aAB}$ & $6.14 \pm 0.44 \mathrm{aA}$ & $6.21 \pm 0.29 \mathrm{aA}$ & $2.58 \pm 0.24 \mathrm{abAB}$ & $2.65 \pm 0.36 \mathrm{abB}$ \\
\hline
\end{tabular}

All values are mean \pm standard deviation. Means in the same column with different superscripts differ significantly: ${ }^{*} \mathrm{P}<0.05$. Means with different superscripts in the same row indicate significant difference: ${ }^{*} \mathrm{P}<0.05$.

YHFC: Yakhni of goshtaba with fat (20\%); YLFC: Yakhni of goshtaba with fat (10\%); YGG1: Yakhni of goshtaba with fat (10\%)+guar gum (0.5\%); YGG2: Yakhni of goshtaba with fat (10\%)+guar gum (1.0\%); YGG3: Yakhni of goshtaba with fat (10\%)+guar gum (1.5\%); YXG1: Yakhni of goshtaba with fat $(10 \%)+x a n t h a n$ gum (0.5\%); YXG2: Yakhni of goshtaba with fat (10\%)+xanthan gum (1.0\%); YXG3: Yakhni of goshtaba with fat (10\%)+xanthan gum (1.5\%); YGXG1: Yakhni of goshtaba with fat (10\%)+guar/xanthan gum (0.5\%); YGXG2: Yakhni of goshtaba with fat (10\%)+guar/xanthan gum (1.0\%); YGXG3: Yakhni of goshtaba with fat (10\%)+guar/xanthan gum (1.5\%). 


\section{Microbial evaluation}

The canned yakhni samples were analyzed for the presence of aerobic or anaerobic mesophilic and thermophilic bacteria, yeast and mould counts immediately after canning. The results indicated that microbial counts including total plate count, total coliform count, anaerobic plate count, total clostridium count, yeast and mould counts were not detected in any yakhni sample after processing. The absence of microbial counts was because of the severity of thermal treatment during canning, thus all samples were commercially sterile. The thermal treatment was therefore, adequate to achieve commercial sterility and hence the safety of product. Our results were in accordance with earlier researchers [6] who studied UHT processed milk and found commercial sterility after thermal processing. Similar results were also observed for retort processed rose flavoured milk during 90 days storage period [7].

\section{Conclusion}

The results of this study concluded that yakhni can be preserved by thermal processing without any detrimental effects to the proximate composition which is important quality attribute affecting the consumer acceptability of food products. The results of microbial evaluation after canning revealed that microbial counts were not detected in any sample immediately after canning, thus indicate the thermal sterility of the product.

\section{References}

1. BD Diagnostics (2009) Difco \& BBL Manual, Manual of Microbiological Culture Media Second Edition. Copyright by Becton Dickinson and Company, Sparks, Maryland.

2. Billy TJ, Wachsmuth IK (1997) Hazard analysis and critical control point systems in the United States Department of Agriculture regulatory policy. Rev Sci Tech 16(2): 342-348.

3. Rajkumar V, Dushyanthan K, Das AK (2010) Retort pouch processing of Chettinad style goat meat curry-a heritage meat product. J Food Sci Tech 47(4): 372-379.

4. Shakila RJ, Raj BE, Felix N (2015) Sensory, Biochemical, and Microbial Qualities of Canned Farmed Cobia Processed with Indian Spice Masala Mix. J. Aquatic Food Product Tech 24(4): 330-339.

5. AOAC (1990) Official Methods of Analysis of the Association of Official Analytical Chemists, $\left(18^{\text {th }}\right.$ edn). Horwitz William Publication, Washington, DC, USA.

6. Hassan A, Amjad I, Mahmood S (2009) Microbiological and physicochemical analysis of different UHT milk available in local market. As J Food Ag-Ind 2(03): 434-447.

7. Anandh CP, Ramasamy D, Surendraraj A, Gnanalakkshmi KS (2014) Process optimization and shelf life study of retort processed rose flavoured milk. Intern J Food Agric Veter Sci 4 (1): 1-11.

\section{Your next submission with Juniper Publishers} will reach you the below assets

- Quality Editorial service

- Swift Peer Review

- Reprints availability

- E-prints Service

- Manuscript Podcast for convenient understanding

- Global attainment for your research

- Manuscript accessibility in different formats ( Pdf, E-pub, Full Text, Audio)

- Unceasing customer service

Track the below URL for one-step submission https://juniperpublishers.com/online-submission.php 